\title{
PEDAGOGI YESUS DALAM PERSPEKTIF PROGRESIFISME PENDIDIKAN
}

\author{
Yakobus Ndona ${ }^{(*)}$, Liber Siagian ${ }^{1)}$ dan Sampitmo Habeahan ${ }^{1)}$ \\ ${ }^{1}$ Prodi Pendidikan Kewarganegaraan, Fakultas Ilmu Sosial, Universitas Negeri Medan
}

\begin{abstract}
Jesus Christ is not only a founder of Christianity. Jesus is from pedagogical perspective including an educational figures with the power of charisma who until now has influenced to the world of Christianity. The charisma pedagogy of Jesus appears in authoritative teaching, the charismatic, delivery of messianic expectations and a distinctive educational pattern. A study of a gospels, reveals that the pedagogy of Jesus was not oriented toward the inculcation of religious laws as done by the Jewish rabbis. Jesus education focused on renewing the heart based on the value of the kingdom of God. Jesus did not build a formal class but made Himself and the environment around Him as a learning laboratory. This pattern shows that the pedagogy of Jesus has both parallel and contradiction with the various educational which developing in the world of education. This paper examines the richness of Jesus pedagogy as seem from a progressivism perspective of an education. The philosophical hermeneutic analysis found the substance, pattern and objective value of Jesus education. Then, through reflection and heuristics, we find contextual values that have implications for the world of Christian education and is an inspiration for educational activists today. Keywords: Jesus, pedagogy, progressivism
\end{abstract}

\begin{abstract}
Abstrak
Yesus Kristus tidak hanya seorang pendiri kristianitas. Yesus, dari perspektif pedagogik termasuk tokoh pendidikan dengan kekuatan kharisma yang sampai sekarang berpengaruh pada dunia kekristenan. Kharisma pedagogi Yesus tampak dalam pengajaran yang otoritatif, berkharisma, penyampaian harapan-harapan mesianik, dan pola pendidikan yang khas. Telah terhadap kitab-kitab Injil memperlihatkan bahwa pedagogi Yesus tidak berorientasi pada penanaman hukum-hukum agama seperti yang dilakukan para rabi Yahudi. Pendidikan Yesus terfokus pada pembaharuan hati yang berlandaskan pada nilai-nilai kerajaan Allah. Yesus tidak membangun kelas-kelas formal, tetapi menjadikan diri-Nya dan lingkungan sekitar sebagai laboratorium belajar. Pola ini memperlihatkan bahwa pedagogi Yesus memiliki paralel sekaligus kontradiksi dengan berbagai aliran pendidikan yang sekarang berkembang dalam dunia pendidikan. Tulisan ini mengkaji kekayaan pedagogi Yesus yang dilihat dari perspektif progresifisme pendidikan. Analisa hermeneutika falsafati menemukan substansi, pola dan nilai objektif pendidikan Yesus, kemudian lewat gerak refleksi dan heuristika menemukan nilai kontektual yang berimplikasi bagi dunia pendidikan Kristen, dan inspirasi bagi para penggiat pendidikan dewasa ini.
\end{abstract}

Katakunci : pedagogi, progresifisme, Yesus,

25 | Korespondensi mengenai artikel dapat dilakukan kepada:

Yakobus Ndona, Universitas Negeri Medan-Jl. William Iskandar Ps. V, Kenangan Baru, Kec. Percut Sei Tuan,

Kabupaten Deli Serdang, Sumatera Utara 20371

Email: yakobusndona@unimed.ac.id 


\section{PENDAHULUAN}

Salah satu gelar paling dominan yang dikenakan kepada Yesus adalah guru (Christian Jonch, 2007). Kalangan Kristen bahkan menyebut-Nya sebagai guru agung atau guru utama. Penyebutan guru, tidak hanya menggambarkan diri-Nya sebagai seorang pengajar, tetapi juga model hidup bagi para pengikut-Nya. Orang-orang Kristen menjadikan hidup Yesus sebagai model dalam membangun spiritualitas dan moralitas kehidupan. Pemodelan secara khusus terjadi dalam dunia pendidikan. Dunia pendidikan Kristen, pada satu sisi harus merujuk pada gaya pendidikan Yesus sebagai model pedagogik sejati. Gaya pendidikan Yesus yang diterapkan 2000 tahun lalu, dengan posisi iniakan selalu dinggap relevan dan memberi pesona istimewa. Pertanyaan yang muncul adalah apa keunggulan dalam gaya pendidikan Yesus. Apa relevansinya bagi dunia pendidikan sekarang? Sekilas model pendidikan Yesus menyerupai pendidikan ala seminari dan pesantren, namun terdapat perbedaan mendasar sehingga tidak dapat disamakan begitu seja. Dunia pendidikan Kristen, pada sisi lain juga harus beradaptasi dengan berbagai model dan sistem pendidikan yang berbasiskan aliran-aliran pendidikan dari masa ke masa. Pendidikan Kristen, akan selalu ada dalam ketegangan antara gaya pendidikan Yesus sebagai guru utama, dan keharusan untuk beradaptasi dengan berbagai model pendidikan yang sedang berkembang. Pertanyaan yang muncul apa kekhasan model pendidikan Yesus. Apakah kesamaan dan perbedaanantara model pendidikan Yesus dengan model-model pendidikan yang berkembang dari zaman ke zaman. Tulisan ini menggambarkan model pendidikan Yesus dari perspektif aliran progresifisme pendidikan. Apakah aspek-aspek kesamaan dan perbedaan antara model pendidikan Yesus dengan progresifisme pendidikan, serta apa relevansinya bagi dunia pendidikan dewasa ini.

\section{METODE PENELITIAN}

Tulisan merupakan kajian pustaka terhadap pola pendidikan Yesus yang ditinjau dari sudut pandang progresifisme pendidikan. Kajian menggunakan pendekatan kualitatif. Penggunaan pendekatan ini didasarkan pada pertimbangan bahwa kajian beroriantasi pada pengungkapan makna. Pengungkapan makna lebih membutuhkan interpretasi daripada perhitungan angka-angka. Data dikumpulkan lewat studi dokumen 
terhadap kisah hidup dan pelayanan Yesus dalam kitab-kitab Injil, kemudian dianalisa dengan menggakan pola hermenautika falsafati, yakni vertehen, terjemahan, dan interpretasi. Interpretasi memanfaatkan tulisan-tulisan yang berbicara tentang progresifisme pendidikan, dan mendekati dengan pola lingkaran hermeneutika, yakni bagian-bagian menjelaskan keseluruhan dan keseluruhan menjelaskan bagian-bagian

\section{HASIL DAN PEMBAHASAN}

\section{Yesus Sang Guru}

Masyarakat umum kebanyakan mengenal Yesus sebagai pendiri kristianitas. Perjanjian Baru memberi bermacam gelar terhadap Yesus, seperti guru, mesias, penyelamat, Anak Allah, Tuhan dan sebagainya (Tumbel, 2016). Berangkat dari hidup, terutama aktifitas pelayanan Yesus di depan publik, gelar yang paling tepat dikenakan kepada Yesus adalah guru (Christian Jonch, 2007). Terlepas dari persoalan teologis, seperti keilahian dan kemanusiaan-Nya, Yesus memang melakukan aktifitas sebagai seorang pendidik. Di hadapan para murid dan musuhmusuh-Nya, Yesus adalah sang guru, yang ajaran-Nya diyakini sebagai kebenaran dan hidup, dan memiliki pesona pribadi yang mengagumkan serta memikat hati (Christian Jonch, 2007).

Kitab-kitab Injil melukiskan bahwa Yesus sering disapa sebagai guru (Yohanes 13:13.). Sebutan ini juga disampaikan oleh para pemuka agama Yahudi (Lukas 19:38-40), para musuh dan setan-setan (Matius 4:3). Bagi orang Yahudi, Yesus disejajarkan dengan para rabi lain. Bisa dipastikan bahwa identitas sebagai guru diterima oleh semua kalangan di zaman itu (Christian Jonch, 2007). Pihak-pihak yang menolak-Nya bukan karena mereka meragukan kerabian-Nya, tetapi karena pengakuan-Nya sebagai mesias (Lukas 4:16-30).

Gelar guru yang dikenakan pada Yesus setidaknya berpijak pada dua hal, yakni aktifitas-Nya mengajar dan melakukan pemuridan. Kitab-kitab Injil memberi kesaksian bahwa selain berdoa dan mengerjakan mukjizat, kegiatan Yesus yang cukup dominan adalah mengajar. Ia masuk keluar rumah ibadat, menyusuri kota dan desa, pasar-pasar dan jalan-jalan, tanah datar dan berbukit, rumah-rumah dan pesisir pantai untuk mengajar. Aktivitas ini terus dijalankan sampai menjelang akhir hidupNya. Sesungguhya seluruh hidup Yesus, termasuk kematian-Nya diabdikan untuk 
misi pengajaran ini. Yesus memang seorang pengajar, tepatnya seorang pengajar berkarismatis (Tafonao, 2020).

Pengajaran Yesus terfokus pada tema kerajaan Allah (Christian Jonch, 2007). Injil Matius mengatakan bahwa Yesus mengajar dan memberitakan Injil Kerajaan Surga, melenyapkan segala penyakit dan kelemahan Israel (Matius 4:23; bdk.9:35). Misi ini dimulainya dari Galilea dengan menyusuri daerah sekitar sungai Yordan sampai ke Yerusalem. Rumusan pengajaran Yesus secara ringkas disampaikan oleh Markus, waktunya telah genap, kerajaan Allah sudah dekat (1:15).

Berbeda dengan ketiga Injil lain, Injil Matius tidak menyebut istilah kerajaan Allah, tetapi kerajaan surga. Hanya dua kali dalam seluruh Injilnya, Matius menyebut kerajaan Allah. Apakah ada perbedaan konsep kerajaan Allah dengan kerajaan surga? Orang Yahudi biasanya enggan menyebut nama Allah atau Yahwe, sebagai bentuk penghormatan kepada-Nya. Dapat terjadi Yesus sendiri menggunakan beragam istilah, namun kemungkinan itu kecil mengingat hanya Matius yang menggunakan istilah itu. Dapat dipastikan Matius sendiri tidak membedakan kerajaan surga dengan kerajaan Allah (Pramudya, 2000).

Yesus juga melakukan pemuridan. Seperti umumnya rabi-rabi Yahudi, Yesus memiliki sejumlah pengikut yang disebut dengan murid-murid-Nya. Para penginjil memberi kesaksian bahwa Yesus memulai misi-Nya dengan menjumpai kedua pasang bersaudara yang sedang menjalaikan di danau Galilea (Matius 4:18).Yesus, dalam perjumpaan yang singkat itu mengajak mereka untuk mengikuti Dia demi suatu misi baru, yakni menjala manusia. Keempat bersaudara meninggalkan jala dan keluarga lalu segera mengikut Yesus.Yesus juga memanggil Lewi pemungut cukai (Lukas 5:27-32), demikian seterusnya sampai berjumlah duabelas orang dan menetapkan mereka menjadi rasul. Mereka adalah Simon yang juga di disebut Petrus dan Andreas saudaranya, Yakobus dan Yohanes, Philipus dan Bertolmeus, Matius dan Thomas, Yakobus anak Alfeus, Simon yang disebut orang Zelot, Yudas anak Yakobus, dan Yudas Iskariot (Markus 3:13-21).

Penetapan kedua rasul merupakan keputusan penting dalam periode pelanyanan Yesus. Yesus tidak sembarangan memilih orang, sebab kelompok ini 
adalah kelompok inti dalam pelayanan. Lukas mencatat bahwa menjelang menetapan kelompok dua belas, Yesus berdoa sepanjang malam (Lukas 6:12). Dua belas rasul adalah orang-orang yang akan dididik secara khusus dan menghabiskan banyak tenaga dan waktu-Nya. Yesus sadar bahwa kelangsungan seluruh misi-Nya tergantung pada kelompok ini. Ia menyertakan mereka dalam seluruh pelayanan, juga mengakhiri babak pelayanan-Nya bersama kelompok kecil ini pada sebuah ruang di Yerusalem (Matius 26:17:--29). Yesus benar-benar mempersiapkan mereka untuk menjadi pemimpin-pemimpin dan peletak dasar gereja. Di antara kedua belas rasul ini, Yesus memiliki kelompok yang terdekat yang dikenal dengan tiga murid atau trio-rasul. Mereka adalah Petrus, Yakobus dan Yohanes (Markus 9:2).

Selain kelompok rasul, Yesus masih memiliki kelompok lain dengan jumlah yang cukup besar. Mereka adalah orang banyak yang datang dan pergi, yang hatinya tergerak oleh pengajaran dan mujizat-mujizat Yesus (Matius 8:1-9:38). Ada kelompok tujuh puluh murid, yang tampaknya memiliki komitmen khusus. Meskipun dengan kadar yang berbeda, Yesus juga melibatkan kelompok ini dalam pelanyanan-Nya untuk memberitakan Injil dan menyembuhkan orang-orang sakit (Lukas 10:1-24). Ada juga kelompok lima ratus orang, yang menurut catatan Lukas mereka menyaksikan kenaikan Yesus ke Surga (Matius 28:19).

\section{Idiologi Pendidikan Progresifisme}

\section{Latar Belakang Sejarah}

Progresivisme pendidikan memiliki asal usul dari gerakan reformasi umum sosial-politik yang menandai kehidupan Amerika padaakhir abad XIX dan awal abad XX. Kelahiran aliran ini berkaitan dengan situasi Amerika yang sedang menyesuaikan diri dengan kaum urban (Gartei, 2017). Progresivisme kemudian berkembang menjadi aliran pemikiran pada pertengahan abad ke-20 dan selama 20 tahun menjadi sangat kuat di Amerika Serikat, dan membawa pembaruhan dunia pendidikan di seluruh dunia.

Tokoh utama aliran ini adalah Francis W. Parker (Gartei, 2017). Belajar dari pengalaman sebagai guru di sekolah desa, lalu kuliah filsafat di Jerman, serta observasi di sekolah Pestalozzi dan Froebel, ia mengembangkan pola pendidikan progresif dalam perannya sebagai instruktur sekolah di Quincy, Massachusstes, 
1875 dan kepala institut Chicago (D. F. Labaree, 2005). Selain Parker juga ada tokoh lain seperti William Kilpatrick dengan pengembangan metode proyeknya (D. F. Labaree, 2005). Gerakan ini juga didukung oleh organisasi-organisasi pendidikan di AS, seperti Progressive Education Association, yang secara continue menerapkan pola pendidikan ini, dan Association for Childhood Education, The American Education of Teacher (Gartei, 2017).

\section{Prinsip Filosofis dan Orientasi Pendidikan Progresifisme}

Progresivisme sering diidentikan dengan pandangan liberal, the liberal road to culture, yang menekankan fleksibelitas, tidak kaku (tidak menolak perubahan, tidak terikat oleh suatu doktrin tertentu), curios (ingin mengetahui, ingin menyelidiki), toleran dan open-minded (Elena Achkovska Leshkovska and Suzana Miovska Spaseva, 2016).

Harus dikatakan bahwa aliran ini tidak memiliki konsep pendidikan yang komprehensif tunggal. Mereka berbeda dalam pemikiran dan praktik, namun ada beberapa prinsip umum dalam aliran ini. Pertama, pemfokusan pada realitas konkrit dunia. Dalam latar belakang prakmatisme Jhon Dewey, progresifisme memfokuskan perhatian pada realitas konkrit dunia (Elena Achkovska Leshkovska and Suzana Miovska Spaseva, 2016). Dunia bukan dalam arti alam semesta tetapi dunia hidupyang selalu berproses. Dunia adalah dinamika hidup manusia, perjuangan dan aktifitasnya. Dunia, dengan kata lain adalah pengalaman hidup manusia. Individu dengan berbagai kemampuan yang dimiliki mengisi pengalamannya, sehingga menghasilkan pemikiran, simbol-simbol, dan komunikasi dengan pihak luar (Elena Achkovska Leshkovska and Suzana Miovska Spaseva, 2016).

Kedua, pengetahuan induktif. Progresifisme, dengan menekankan aspek dunia konkrit atau dunia pengalaman, berorientasi pada pengetahuan induktif. Aliran ini menolak pengetahuan yang bersumber dari apriori. Berdasarkan pengalaman-pengalamannya orang membangun kesimpulan. Dalam proses ini, nalar memainkan peranan untuk membangun kebenaran dengan berpijak pada pengetahuan yang induktif(Nanuru, 2013). 
Berangkat dari pemikiran ini, progresif tidak mengandalkan kurikulum untuk mengirimkan pelajaran kepada siswa. Bagi mereka kurikulum harus datang dari anakdenganpotensi dan bakat yang beraneka ragam(Nanuru, 2013).

Ketiga, relatifisme nilai. Dengan penekanan padaempirisme dan pengetahuan induktif, aliran ini memandang nilai sebagai relatif. Nilai tidak ada dengan sendirinyakarena apriori seperti pada Kant dan Scheler (Schönecker and Schmidt, 2018). Tetapi terbentuk oleh pengalaman konkret manusia, aposteriori. Sesuatu menjadi bernilai bila memiliki kecocokan dan teruji dalam pengalaman konkret manusia dalam relasi dengan orang lain (Fred, 2014). Yang baik adalah yang mendatangkan kesejahteraan bagi masyarakat. Nilai berdimensi personal sekaligus sosial. Nilai, yang pasti nilai ditentukan oleh faedahnya, baik bagi diri sendiri (intrinsik) maupun bagi masyarakat (Fred, 2014). Pemahaman ini berangkat dari konsep pragmatisme yang memandang aku sebagai bentukan lingkungan, dan masyarakat sebagai bentukan aku-aku. Aku mengerti tentang dirinya sejauh aku mengenal dan memahami orang lain, sebaliknya masyarakat terbentuk oleh individu-inividu (Fred, 2014). Dengan demikian nilai menjadi relatif, dinamis dan temporal. Pendapat ini juga didukung oleh Hans Valhinger. Ia mengatakan bahwa pengetahuan itu hanya memiliki arti praktis. Validitas pengetahuan adalah kegunaannya bagi kehidupan di dunia (Fred, 2014).

Keempat, penekanan pada pribadi manusia. Progresifisme, dalam latar belakang pemikiran spiritualistik dan kreatifitas dari Froeben dan Montessori serta perkembangan humanisme baru, memberi penekanan yang kuat pada pribadi manusia yang memiliki harkat dan martabat (D. F. Labaree, 2005). Manusia adalah makhluk yang berevolusi secara biologis, sosial, psikologis. Ia terus berkembang ke arah yang lebih baik. Individu adalah organisme aktif yang memiliki ratio dan energi untuk terus merekonstruksi, menginterpretasi dan mereorganisasikan pengalamannya, sehingga terus menemukan pengetahuan untuk kemajuan dirinya. Lembaga pendidikan, karena itu harus menjadi wadah pengembangan daya kreatif anak agar memiliki kemampuan untuk mengatasi persoalan dan pengembangan diri dan masyarakat (Gartei, 2017).

Anak tidak hanya terdiri dari kesatuan badan dan jiwa, tetapi memiliki keunggulan dalam kecerdasan, kreatifitas dan dinamisme untuk memecahkan 31 |Pedagogi Yesus Dalam Perspektif Progresifisme Pendidikan ..., Yakobus, Liber, Sampitmo Jurnal Christian Humanioran | http://e-journal.iakntarutung.ac.id/index.php/humaniora 
persoalan-persoalan dan terutama untuk mengaktualisasikan diri dalam pengalaman. Untuk itu anak harus diberi keleluasaan dan kebebasan untuk berekspolasi dengan lingkungan dan kejadian-kejadian di sekitarnya, terutama dengan kejadian-kejadian kebudayaan. Sekolah harus dikondisikan sedemikian rupa sehingga anak dengan leluasa berelasi dengan masyarakat dan alam. Bisa dikatakan anak belajar dari hidup, dan dalam pengalamannya itu ia dapat menemukan nilai-nilai dasar yang diperjuangkan oleh sebuah negara (D. F. Labaree, 2005).

Kelima, terstruktur bebas.Aliran ini berpegang bahwa pendidikan merupakan proses untuk membebaskan anak (Nanuru, 2013). Karena itu mereka menolak praktik sekolah tradisionaldengan cenderungan (1) guruotoriter, (2) ketergantungan eksklusif pada metode instruksi atau buku pelajaran, (3) pembelajaran pasif dengan menghafal data faktual, (4) dinding filsafat pendidikan yang berusaha untuk mengisolasi pendidikan dari realitas sosial, dan (5) penggunaan rasa takut atau hukuman fisik sebagai pembelajaran disiplin. Kaum progresif juga bersepakat bahwa(1) anak harus bebas untuk berkembang secara alami; (2) minat anak dirangsang oleh pengalaman langsung sebagai stimulus terbaik untuk belajar; (3) guru harus menjadi narasumber dan menjadi pemandu kegiatan belajar; (4) harus ada kerjasama yang erat antara sekolah dan rumah; dan (5) sekolah harus menjadi laboratorium untuk reformasi pedagogis dan eksperimen. Sekolah harus menjadi tempat bagi anak-anak untuk menjalani percobaan, bermain dan mengekspresikan diri (Nanuru, 2013).

Keenam, anak sebagai pembelajar. Seperti umumya aliran-aliran liberal, pendidikan progresifberfokus pada anak sebagai pembelajar. Karena itu penekanan lebihpada pengalaman dari pada kemampuan verbal dan sastra, dan mendorong kerja sama kegiatan belajar kelompok. Mereka bereksperimen dengan model-model alternatif, seperti kegiatan organisasi, memanfaatkan ekstra kurikuler, pemecahan masalah, metode proyek, dan sebagainya.

Ketujuh, model pembelajaran berbasis masalah. Penekanan pada pengalaman mendorong progresifisme menciptakan model pembelajaran berbasis 
pemecahan masalah, kunjungan lapangan, ekspresi seni kreatif, dan kerja proyek (D. F. Labaree, 2005). Di atas semua ini, kaum progresif melihat proses pembelajaran aktif, menarik, dan selalu berubah.Untuk itu sekolah tidak bisa dicukupkan hanya dengan satu ruang kelas, tetapi juga membutuhkan ruang kerja, laboratorium ilmu, studio, ruang seni, ruang masak, tempat olahraga, perkebunan, dan sebagainya. Dengan prosedur dan fasilitas yang memadai otomatis akan membangun fisik, sosial, emosi alamiah, dan kesempatan yang luas untuk mengekpresikan pikiran. Pembelajaran harus dalam atmosfir yang informal, dengan penekanan pada sebanyak mungkin aktifitas. Mereka akan belajar lebih baik jika mereka bergerak dan bekerja menurut cara mereka sendiri.

Kedelapan, sekolah sebagai egen reformasi sosial. Sejumlah kelompok dalam progresifisme pendidikan memiliki kecenderungan untuk melihat sekolah sebagai agen reformasi sosial. Kesamaan langkah sekolah dengan gerak masyarakat dan penekanan pada ekplorasi alam dan lingkungan dimaksudkan agar kelak anak nantinya dapat menjadi agen reformasi sosial. Pembaharuan sekolah menjadi benih pembaharuan dalam masyarakat (D. F. Labaree, 2005).

\section{Wajah Pendidikan Yesus}

\section{Guru Pembaharu}

Yesus, pada zaman-Nya tampil sebagai pembaharu. Ia seorang guru yang berbeda dari para rabi Yahudi. Bila para rabi Yahudi dicari oleh calon-calon murid, sebaliknya Yesus justru mencari calon-calon murid-Nya sendiri (Falowe Vivtor Olugbenga, 2015). Berbeda dengan para rabi Yahudi yang memperoleh para murid dari golongan elite, yakni calon-calon imam zaduki dan calon pengajar taurat, farisi, Yesus justru memanggil orang-orang pinggiran untuk menjadi murid-murid-Nya. Ada Matius, pegawai pajak yang pada masa itu dianggap golongan pendosa (Matius 9:9). Murid-murid-Nya yang lain adalah nelayannelayan miskin. Hanya Yudas yang berasal dari masyarakat perkotaan, Yudea (Kamus Alkitab Sabda). Di luar kelompok dua belas rasul, ada juga Bartimeus yang disembuhkan dari kebutaan, dan ada Maria Magdalena, wanita pelacur yang diselamatkan dari hukuman rajam (Yohanes 8:2-11) dan beberapa wanita lain yang mengurusi keperluan pelayanan-Nya. Sang guru merekrut orang-orang yang 
dalam tradisi Yahudi dianggap sebagai pihak yang tidak berhak atas pendidikan. Pilihan pada golongan ini menyebabkan reaksi dingin dan penolakan para pemuka agama Yahudi (Markus 2:16).

Orientasi pengajaran Yesus juga berbeda dengan tradisi pendidikan Yahudi. Jika para rabi Yahudi terfokus pada pendidikan taurat, sebab bagi mereka taurat adalah jalan keselamatan (Andrianti, 2013), Yesus justru melepaskan diri dari keterikatan itu. Bagi Yesus, seperti dikatakan oleh Paulus, bukan taurat yang menyelamatkan manusia, sebab tidak ada seorang dapat melaksanakan seluruh hukum taurat (Yakobus Ndona, 2020). Pengajaran Yesus terfokus pada hukum kasih, yakni mengasihi Allah lebih dari segala sesuatu, dan mengasihi sesama seperti mengasihi diri sendiri (Markus 12:10). Penekanan ini menyebabkan arah pengajaran ini berbeda tajam dengan para rabi Yahudi. Jika dalam taurat ditegaskan siapa yang bersalah harus dihukum, pada Yesus diajarkan untuk mengampuni kesalahan sesama, bukan hanya sekali atau dua kali, tetapi tujuh puluh kali tujuh kali (Matius 18:22); bukan mata ganti mata, gigi ganti gigi, tetapi memberikan pipimu yang lain lagi bila pipimu yang satu ditampar (Lukas 6:29).Yesus, secara radikal mengajarkan kepada murid-Nya untuk mengasihi musuh (Lukas 6:27:29).

Kasih, bagi Yesus lebih penting dari segala-galanya. Kasih mengatasi seluruh hukum taurat dan kitab para nabi. Setiap orang yang hendak beribadah, namun teringat akan dosa terhadap saudaranya, hendaklah ia berdamai dahulu sebelum beribadah kepada Allah (Matius 5:21-26). Dalam semangat ini, Yesus menentang secara terbuka hukum taurat yang mengajarkan bahwa penderitaan disebabkan karena dosa(Tumbel, 2016). Dengan tegas, Yesus mengatakan bahwa penderitaan bukan karena kutukan Allah karena karena dosa yang bersangkutan atau dosa orang tua dan para leluhurnya, tetapi untuk menunjukkan kemuliaan Allah (Yohanes 9:3). Penderitaan sesama adalah ruang untuk menyatakan kasih Allah kepadanya. Dalam latar belakang ini bisa dipahami bahwa Yesus mengindetikkan diri dengan orang yang paling hina, dan menjadikan pelayanan 
terhadap orang yang bernasip demikian sebagai syarat memperoleh keselamatan (Matius 25:40).

\section{Memandang Manusia sebagai Pribadi}

Pedagogi Yesus bersumber dari pemikiran fisosofis tentang manusiasebagai pribadi (Tumbel, 2016). Yesus meyakini bahwa manusia memiliki kemampuan untuk mengatasi masalah, mengubah hidup serta lingkungan. Setiap orang, siapapun dia, termasuk para wanita dan anak-anak, para janda dan orang-orang miskin, para pendosa dan orang-orang terpinggirkan adalah pribadiyang memiliki kekurangan sekaligus kemampuan untuk memperbaiki dan mengembangkan diri. Kelompok orang-orang kecil yang sering tak diperhitungkan para pemuka agama Yahudi, oleh Yesus ditempatkan pada martabat yang sama dengan kaum elite (Lukas 9:48; Matius 19:5). Mereka juga memiliki kemampuan untuk mengubah dan mengembangkan diri (Falowe Vivtor Olugbenga, 2015).

\section{Pendidikan Kebijaksanaan Hidup}

Berangkat dari pemikiran tentang manusia sebagai pribadi, Yesus memfokuskan diri pada pembentukan kebijaksanaan hidup. Istilah kebijaksanaan mengacu pada kata Latin sapientia, yang berartikecakapan menggunakan akal budi dan bertindak secara tepat untuk kebaikan (Bagus, 2005). Dunia filsafat menempatkan kebijaksanaan pada ratio praktis manusia. Pendidikan kebijaksanaan berpusat hati, bukan pada disiplin berpikir. Yesus menekankan hati yang mengasihi, yakni mengasihi Allah dan sesama (Lukas 10: 27), hati yang mengampuni (Matius 6: 14), hati yang berbelas kasih, terutama kepada orangorang kecil yang terpinggirkan dalam masyarakat (Matius 25: 31-46); hati yang sabar, tidak sombong (Lukas 14: 11), dan tidak menghakimi (Matius 7: 1-2). Hanya dengan hati yang demikian para murid Yesus akan berpartisipasi dalam pembangunan dunia baru atau Kerajaan Allah di dunia.

Pendidikan hati bermuara pada pembentukan nurani yang membangun relasi dengan yang ilahi, yang akhirnya bermuara pada keyakinan bahwa takut akan Tuhan sebagai permulaan pengetahuan (Amsal 1:7). Pendidikan kebijaksanaan bertumpu pada keyakinan bahwa manusia diberi hati untuk berpikir supaya bisa hidup dan bekerja sesuai rencana Allah. Pendidikan kebijaksanaan menekankan hikmat sebagai pegangan hidup (Mumuni, 2019). Bagi Yesus hidup 
dalam hikmat berarti membangun hidup dengan nilai-nilai yang mewujudkan kasih kepada Allah dan sesama. Karena itu yang penting bukan pengetahuan melainkan tranformasi cara pikir dengan hati yang bersikap kritis terhadap nilainilai, keyakinan, dan norna-norma yang berlaku.

\section{Menempatkan Diri sebagai Laboratorium Hidup}

Yesus meletakkan hidup-Nya sebagai laboratorium belajar bagi para muridNya. Yesus mengatakan kepada para murid-Nya “ikutlah Aku!(Markus 1:17-18) dengan maksud untuk belajar dari hidup-Nya. Ketika Petrus dan saudara-Nya dipanggil, Yesus mengatakan marilah dan kamu akan melihatnya. Pernyataan ini dimaksudkan agar mereka melihat langsung keseharian Yesus. Pada kesempatan lain, Yesus mengatakan, “tinggalah bersama Aku!”(Yohanes 16:6), supaya mereka mengalami pergumulan hidup Yesus. Ia menempatkan hidup-Nya sebagai sumber belajar atau laboratorium hidup bagi para murid-Nya.

Dengan menempatkan hidup sebagai sumber belajar tidak berarti bahwa Yesus mengekslusifkan para murid-Nya dari dunia luar, tetapi supaya mereka mengalami langsung praktik dan peristiwa hidup Yesus. Yesus tidak ingin mendoktrin, tetapi membiarkan para murid menemukan makna dari kebersamaan dengan diri-Nya. Pembelajaran Yesus tidak berangkat dari kesimpulan. Ia mengarahkan para murid-Nya secara induktif menemukan kebenaran-kebenaran yang dipancarkan dalam keseharian hidup-Nya kemudian menarik kesimpulannya sendiri. Kadangkala Yesus melakukan croscek terhadap pemahaman para muridNya. Ia bertanya kepada mereka, "apa kata orang tentang Aku”, disusul dengan pertanyaan, "apa katamu tentang Aku" (Matius 16:16). Pertanyaan ini disampaikan setelah sekian lama para murid bersama dengan Dia. Ia hendak mengecek sejauh mana mereka memahami diri-Nya dari apa yang Ia lakukan.

Penempatan diri sebagai laboratorium hidupberkaitan seluruh hidup Yesus yang menghadirkan substansi pengajaran. Subtansi dasar pengajaran Yesus adalah Kerajaan Allah (Marlen Tineke Alakaman, 2015). Yesus tidak hanya mengajar tentang Kerajaan Allah, tetapi menghadirkan Kerajaan Allah lewat belas kasih dan keperpihakan terhadap orang-orang kecil, pengampunan terhadap musuh, 
penyembuhan terhadap orang sakit, perhatian terhadap orang-orang tertawan dan tertindas dan sebagainya. Ia tidak hanya mengajar tetapi menjalankan apa yang diajarkan(Christian Jonch, 2007). Kekuatan pengajaran Yesus terletak pada kesatuan antara perkataan dan pebuatan-Nya. Dari perkataan Yesus, orang mendengar, dan dari pekerjaan-Nya orang melihat perwujudanKerajaan Allah (Tafonao, 2020). Ketika Yesus mengajarkan tentang terang dunia, orang tidak hanya mendengar, tetapi juga menyaksikan perwujudanpada memelekkan mata sibuta (Matius 9:29-31). Ia tidak hanya memperdengarkan tentang keberpihakan Allah terhadap orang-orang miskin, tetapi juga bergaul dan hidup bersama dengan orang-orang yang tersingkir dalam masyarakat. Ia tidak hanya mengajar tentang kasih terhadap musuh, tetapi juga menyambungkan kembali telinga sang calon eksekutornya (Yohanes 18:11), menghindari penghukuman dan memaafkan mereka yang telah menganiaya dan membunuh-Nya (Lukas 23:34).

Pedogogi Yesus menggambarkan kesatuan antara perkataan dan tindakan Yesus.Tindakan Yesus menjadi dimensi kelihatan dari perkataan, sebaliknya perkataan memberi arti dan makna pada tindakanYesus. Perkataan dan perbuatan saling mendukung dan melengkapi. Perkataan-perkataan Yesus dengan sendirianya menghindari salah paham, sebaliknya tindakan-tindakan Yesus memberi makna terhadap pengajaran Yesus. Dimensi ini membedakan Yesus dengan para rabi Yahudi. Para rabi hanya meramalkan masa depan dan mengartikan kejadian-kejadian dalam sejarah (Sitorus, 2018) tetapi Yesus mengarjakan apa yang telah dikatakan-Nya.

Penempatan hidup sebagai laboratorium tidak hanya menjadikan pengajaran dan tindakan sebagai sumber belajar, tetapi juga berbegai peristiwa yang dialami Yesus.Penerimaan orang-orang kecil terhadap diri-Nya, penolakan para pemuka agama Yahudi, godaan dan pengkianatan terhadap diri-Nya, terutama penderitaan, wafat dan kebangkitan-Nya merupakan sumber belajar bagi para murid-Nya. Dari semua pengalaman itu, mereka menyimpulkan bahwa Ia adalah orang benar(Yohanes 19:35), mesias (Matius 16:16).

\section{Alam dan Lingkungan sebagai Labratorium Belajar}

Yesus juga menggunakan alam sebagai laboratorium belajar. Ia membawa para murid-Nya ke pantai dan mengajak mereka untuk menemukan makna dari 37|Pedagogi Yesus Dalam Perspektif Progresifisme Pendidikan ..., Yakobus, Liber, Sampitmo Jurnal Christian Humanioran | http://e-journal.iakntarutung.ac.id/index.php/humaniora 
kegiatan penangkapan ikan para nelayan (Matius 13:47-52).. Di lain kesempatan, ia membawa para murid ke alam pertanian dan mengajak mereka memaknai kegiatan petani yang sedang menaburkan benih (Markus 4:1-34), pokok anggur, kehidupan para pekerja, bunga bakung, pohon ara, burung pipit, pohon sesawi dan sebagainya. Dunia peternakan juga menjadi laboratorium bagi pendidikan Yesus. Ia memanfaatan padang rumput, kehidupan para gembala, domba-domba dan kambing-kambing, dan para perampok sebagai sumber belajar. Yesus juga membawa para murid-Nya ke bait suci, dan mereka untuk memaknai perilaku orang-orang yang sedang berdoa dan memberi persembahan (Lukas 24:1-4). Pada kesempatan lain Ia mengajak para murid ke pasar (Lukas 20:46), pesta (Yohanes 2:13; 7:1-13), bukit (Matius 5-7), dan mengajak mereka untuk menemukan maknadari berbagai peristiwa yang terjadi.

Penggunaan lingkungan sebagai sumber belajar juga terjadi pada kehidupan para wanita.Ia menunjuk pada iman seorang wanita yang sakit pendarahan, para wanita yang mengadukan ragi ke dalam tepung terigu, imanperempuan Siro-Fenisia, termasuk tingkah laku Marta dan Maria dalam melayani Dia. Menarik bahwa Yesus justru menggunakan golongan orang-orang yang tak didengarkan dalam masyarakat Yahudi sebagai rujukan untuk menemukan nilai kehidupan. Bagi Yesus setiap orang dan segala hal dapat menjadi sumber belajar (Purnama, 2020).

Penggunaan lingkungan sebagai laboratorium paling dalam dalam berbagai perumpaan Yesus. Yesus seringkali menyampaikan pengajaran dalam bentuk perumpamaan. Perumpamaan-perumpamaan itu diambil dari kehidupan konkrit dan lingkungan sekitar (Falowe Vivtor Olugbenga, 2015). Ia memanfaatkan kekayaan ilustrasi hidup untuk membuka pikiran dan membangun kesadaran manusia tentang nilai-nilai peradaban baru yang dinamakan-Nya kerajaan Allah. Dengan perumpamaan-perumpaan itu, Yesus memberikan kesempatan kepada pendengar untuk mencerna, mengerti dan sesegera mungkin mengambil keputusannya sendiri (Matius 13:13-15). 


\section{Mengenal Hati Manusia dan Kehendak Allah}

Keempat Injil menceritakan bahwa pengajaran dan tindakan Yesus seringkali menimbulkan rasa takjub banyak orang (Falowe Vivtor Olugbenga, 2015). "Takjublah orang banyak itu mendengar pengajan-Nya, sebab Ia megajar mereka sebagai orang yang berkuasa dan tidak seperti ahli-ahli taurat" (Matius 7:28-29). Kata "takjub" dalam kitab-kitab Injil dipakai untuk menerjemahkan kata Yunani, exeplhssonto, juga bisa berarti gempar, heran, kagum, terpesona, juga bisa berarti kesal dan marah (Kamus Alkitab Sabda). Ketakjuban disebabkan oleh cara mengajar Yesus yang menyimpang dengan pola-pola tradisional (Mumuni, 2019). Ketika Yesus menyampaikan kata-kata rahmat di rumah ibadat, semua jemaat bersaksi dan heran akan kata-kata indah yang di ucapkan-Nya (Lukas 4:22). Kata heran mungkin saja menunjukkan keterkejutan, kekesalan hati, kejengkelan.Ada kemungkinan orang-orang Nasaret kesal hati karena Yesus mengutip Kitab Yesaya 61: 1-2 tentang karunia Allah bagi orang-orang yang tidak mendapat tempat dalam masyarakat Yahudi.

Efektifitas pengajaran Yesus dengan reaksi ketakjuban tampaknya bersumber dari pemahaman Yesus terhadap hati manusia dan rencana Allah. Keempat injil memberi kesaksian bahwa Yesus mengenal apa yang ada dalam hati manusia. Ia sadar bahwa setiap orang dapat menjadi rendah hati (Lukas 18:13), peduli terhadap sesamanya (Lukas 10:33; Matius 25:31-37), dan merindukan kebenaran Allah dalam hidupnya (Matius 13:23).

Yesus memahami motivasi dari setiap perkataan orang-orang di sekitar-Nya (Lukas 7:36-50; Matius 22:15-22). Ia menyelami pikiran yang menyimpan pertanyaan dan hati yang menyimpan kejahatan, sehingga dapat memberi jawaban secara tepat kepada para lawan bicara sesuai dengan pikiran dan pergumulan hati mereka. Kesan serupa juga diperoleh dalam Matius 13:24-30. Pada teks ini, Matius memperlihatkan bahwa Yesus sungguh sadar bahwa dalam hati manusia, yang baik dan yang jahat bisa tercampur menjadi satu. Ia juga tahu bahwa orang jahat dapat berbuat baik dan orang baik dapat berbuat jahat (Matius 7:11. 22-23). Ia tahu bahwa manusia seringkali dibelenggu oleh ketakutan dan kemalasan, juga oleh iri hati dan egoisme diri (Lukas 15:12. 29), kesombongan (luk 18:9-14) dan 
berbagai kelekatan lain yang melumpuhkan (Yohanes 5:1-18; Matius 19:22), yang menyebabkan sulit bertumbuh dalam iman (Matius 25:14-30).

Matius masih mencatat sejumlah kisah lain. Pada perumpamaan tetang seorang penabur (Matius 13:1-23), Matius memperlihatkan kesadaran Yesus tentang berbagai sikap hati manusia terhadap panggilan Allah. Ada hati yang sulit untuk mengerti, oleh karana kebodohan dan kemalasan, hati yang berbatu-batu, tidak berakar, tidak memiliki pendirian, terombang-ambing oleh berbagai penggoda dunia.Ada hati-hati yang rapuh, yang mudah terhimpit oleh berbagai desakan dan bujuk rayuan si jahat. Ada juga hati yang selalu gelisah dan hawatir akan hidup. Ia juga mengenal hati Israel yang degil, yang memaksa Musa untuk mengijinkan percerceraian (Markus 10:5).

Disisi lain, Yesus juga memahami dengan sungguh rencana Allah. Yohanes menceritakan bahwa Yesus beberapa kali menegaskan sumber pengajaran-Nya berasal dari Allah (Yohanes 8:21-29). Ia mengenal dengan baik kehendak Allah, sebab ia di dalam Allah dan Allah dalam Dia (Yohanes 13:10-12). Sejak awal pelayanan-Nya, Yesus mendalami kehendak Allah dan seluruh hidup-Nya termasuk juga kematian-Nya adalah untuk mewujudkan kehendak Allah.

\section{Pedagogi Yesus dalam Kaca Mata Progresifisme}

Memperhatikan pola pendidikan Yesus danciri khas progresifisme, bisa dikatakan bahwa pola pendidikan Yesus termasuk kategori progresifisme pendidikan. Ia adalah pembaharu idiologi dan sistem pendidikan zaman-Nya. Ada beberapa pertimbangan mendasar yang bisa mengkategorikan sang guru ini dalam aliran pendidikan progresifisme.

Pertama, pembebasan dari sistem pendidikan taurat dan disiplin fisik. Yesus memiliki ciri yang serupa dngan progresifisme yang menolak sistem pendidikan tradisonal yang menekankan pembelajaran hafalan, buku ajar serta terikat pada kurikulum yang kaku. Yesus menolak tradisi pendidikan bangsa-Nya yang terfokus pada (kurikulum) taurat dan disiplin fisik melaksanakan hukum-hukum Yahudi. Pendidikan taurat dikenal dengan keterikatan melaksanakan hukum secara detail. Kaum muda Yahudi, terutama dari kelas zaduki dan farisi diwajibkan menghafal 
hukum taurat dan berlatih untuk melaksanakan. Setiap dahi dan pergelangan tangan anak-anak, palang pintu rumah dan gerbang kampung selalu diikatkan dengan ayatayat Taurat (Ulangan 6:4-9). Yesus membebaskan para murid-Nya dari kebiasan ini. Tidak hanya itu, Yesus juga tidak mengikat diri dengan kurikulum tertentu. Ia juga tidak berada dalam mazhab-mazhab pendidikan zaman-Nya, seperti yamnia dan helel.

Perhatian Yesus bukan pada kurikulum, tetapi pada pribadi setiap orang, yakni pribadi manusia yang memiliki pikiran dan hati, yang bisa berlaku baik sekaligus jahat, yang bisa memperbaiki dan mengembangkan diri. Pendidikan Yesus adalah pendidikan hati, agar dalam kehendak bebasnya orang dapat menemukan dan memilih nilai-nilai kerajaan Allah bagi hidup-Nya.

Kedua, belajar menemukan nilai. Seperti progresifisme, pendidikan Yesus juga menekankan pola induktif. Ia jarang seara langsung menegaskan prinsip-prinsip ajaran-Nya. Ia membiarkan para murid-Nya bergumul dengan berbagai pengalaman dan persoalan untuk menemukan sendiri apa yang harus dilakukan. Ia memberi tugas kepada mereka, lalu menanyakan hasil yang dicapai. Ia memberi kasus agar mereka belajar mengatasinya (Yohanes 6:5-6). Ia mengajak mereka untuk melihat dan berbuat, lalu menangkap nilainya.

Ketiga, sekolah alam. Searah dengan para progresifisme, Yesus tidak membangun kelas-kelas pembelajaran. Pengajaran dan pendidikan Yesus dilangsungkan di mana seja. Dia menjadikan lingkungan dan alam sebagai laboratorium belajar bagi para murid-Nya. Meskipun para murid Yesus adalah orang-orang yang telah mencapai usia dewasa, tetapi mereka tetap diberi kesempatan bereksplorasi dengan lingkungan sekitar, seperti menjala ikan, pertanian, pasar, rumah ibadat dan sebagainya. Dengan jalan itu, mereka tidak didoktrin dengan idiologi-idiologi tertentu, tetapi dibiarkan menemukan sendiri nilai-nilai yang harus menjadi pegangan bagi hidupnya.

Keempat, bekerja dalam kelompok. Serupa dengan progresifisme yang cenderung mengarahkan murid untuk bekerja dalam kelompok, Yesus membiasakan para murid-Nya untuk bekerja dalam tim. Ia mengutus para murid-Nya berdua-dua (Lukas 10:1-12). Ia sadar bahwa dalam tim kelemahan yang satu akan 
disempurnakan oleh kekuatan yang lain. Ia sadar bahwa dalam kesendirian manusia akan mudah tergoda.

Kelima, kemandirian para murid. Sejak awal Yesus sadar bahwa masa hidupNya relatif singkat. Nasip dari misi-Nya tergantung dari kemandirian para murid. Karena itu sejak awal Ia mendidik mereka untuk mandiri dalam menghadapi pekerjaan dan persoalan. Ia mengahadapkan mereka dengan badai dasyat (Matius 8:23-27), orang banyak yang kelaparan (Yohanes 5:5-6), persiapan paskah (Matius 26:17-25), dan sebagainya. Pengalaman kemandirian ini menjadi modal kuat dalam menghadapi misi panjang dan segala persoalan paskah kematian Yesus.

Keenam, membiarkan para murid berkembang secara alami. Yesus mengenal latar belakang, kemampuan, kelemahan, pikiran dan hati para murid-Nya. Ia sadar bahwa suatu ketika bisa dikianati oleh orang-orang dekat-Nya, namun ia memmbiarkan mereka belajar sesuai dengan kemampuan dan cara ia mereka bekerja. Ia tidak memaksa mereka untuk memahami suatu, tetapi mengarahkan mereka menemukan sesuatu. Ia sadar bahwa nilai yang ditemukan sendiri akan jauh lebih kuat dan merangsang mereka untuk mendalaminya lagi. Ia juga sadar bahwa Petrus yang diangkat-Nya menjadi pemimpin dari para murid-Nya cukup temperamental, cenderung mengebu-ngebu sekaligus pengecut (Markus 14:26-31). Ia juga sadar bahwa para murid-Nya bisa bersaing memperebutkan kedudukan paskah kematianNya (Matius 20:20-28). Namun Yesus tidak berintervensi untuk mengatasi semua itu secara bim salabim. Ia membiarkan mereka berkembang secara alami dengan segala resiko yang bisa terjadi. Ia sadar bahwa pertumbuhan yang natural akan jauh lebih kuat dan matang dari pada yang instan. Ini yang menyebabkan kesebelas murid-Nya memiliki komitmen yang kuat dan rela menjadi martir demi nilai-nilai yang diwariskan Yesus.

Di sisi lain agak sulit mengatakan bahwa Yesus sepenuhnya seorang progresifistis.. Yesus, meskipun membiarkan para murid-Nya menemukan sendiri nilai-nilai melalui penglaman hidup dan pelayanan-Nya, namun tetap berpegang teguh pada visi kerajaan Allah.Visi Yesus adalah membangun kerajaan Allah di dunia seperti yang terungkap dalam rumusan doa bapa kami, datanglah kerajaan-Mu 
di bumi seperti di surga (Matius 6:10). Yesus memiliki horison ke depan untuk membangun dunia baru dengan peradaban yang berlandaskan pada nilai-nilai yang dikehendaki Allah, yakni kasih, damai dan adil. Ketiga nilai ini merupakan nilai-nilai peradaban baru untuk mewujdukan Kerajaan Allah dalam dunia. Nilai-nilai ini, bagi Yesus adalah absolut. Kasih, damai dan adil, bagi Yesus diatas segala sesuatu. Ketiganya lahir dari martabat hidup manusia sebagai pribadi. Pembelaan Yesus terhadap hak hidup wanita pelacur, penolakan terhadap stigma kafir, pengampunan terhadap musuh adalah bagian dari perealisasian nilai-nilai utama Kerajaan Allah. Pendidikan Yesus, dapat dikatakan mengarah pada penginternalisasian nilai-nilai ini sebagai jalan perealisasian kerajaan Allah di dunia. Hal ini menyebabkan Yesus kadangkala menunjukkan sikap tegas untuk menunjukan pendirian pada nilai-nilai kerajaan Allah. Ia pernah marah kepada para murid-Nya (Markus 10:14), mengecam para pemuka agama Yahudi (Matius 20;23) dan mengusir para pedagang dari bait suci (Lukas 19:45).

Yesus memang seorang progresifistis, tetapi juga seorang perenialistis sejati. Ia menggunakan pendekatan yang humanis, namun tetap berdiri pada visi dasar kerajaan Allah. Hal ini tentu berbeda dari progresifisme yang berbasiskan pragmatisme John Dewey(Fred, 2014). Yesus menolak perelatifan nilai-nilai utama Kerajaan Allah. Ia bahkan mengorbankan nilai-nilai lain, termasuk nilai-nilai yang dianggap kudus dalam agama demi mewujudkan nilai-nilai Kerajaan Allah. Manusia bukan untuk hukum, tetapi hukum untuk manusia. Pendidikan Yesus terarah pada persiapan para murid-Nya untuk menjadi agen-agen perealisasian tatanan dunia baru dengan nilai-nilai Kerajaan Allah. Ia menjadikan para murid-Nya penabur benihbenih kerajaan Allah seperti biji sesawi atau ragi di tengah masyarakat. Ia membangun suatu komunitas pendidikan sebagai miniatur masyarakat baruyang bermartabat. Pedagogi Yesus, pada aspek pendekatan termasuk progresifisme, namun pada aspek substansi termasuk perenialisme. Yesus adalah seorang progresif sekaligus perenial sejati. 


\section{PENUTUP}

\section{Kesimpulan}

Beberapa hal dapat menjadi kesimpulan sekaligus cacatan refleksi dari pedagogi Yesus. Pertama, pendidikan Yesus tidak bisa direduksi pada satu aliran pedagogik. Pola pendidikan Yesus memang bisa diteropong dengan aliran apa saja, namun kekayaan pedagogik sang guru mengatasi semua aliran pendidikan. Yesus memiliki pola pedagogik yang khas. Karena kekhasannya itu, pola pendidikan Yesus menimbulkan rasa takjub dan berdaya pikat, tidak hanya untuk satu zaman seperti aliran-aliran pedagogik umumya, tetapi selama berabad-abad sampai zaman ini.

Kedua, membutuhkan beragam sudut pandang. Pedagogik Yesus memiliki kekayaan multi dimensi. Kiranya tidak cukup untuk meneropongnya hanya dari satu sudut pandang saja. Penggunaan multi paradigama akan mengungkapkan banyak hal dari pendidikan Yesus yang bisa menjadi inspirasi bagi dunia pendidikan dewasa ini.

Ketiga, harus dikatakan juga bahwa meskipun pendidikan Yesus memiliki kekayaan multi dimensional, namun pendidikan Yesus tidak bisa menjawab semua persoalan pendidikan dewasa ini. Pada zaman-Nya, pola pendidikanYesus memang menakjubkan dan memikat hati orang-orang yang terpinggirkan dalam masyarakat. Meskipun banyak inspirasi yang bisa didapatkan dari pola pendidikan-Nya, namun setiap zaman memiliki tuntutannya sendiri, sehingga pemberlakuan model pendidikan Yesus membutuhkan banyak penyesuaian dalam praktik.

\section{Saran}

Yesus Kristus telah menampakkan kharisma sebagai pendidik sejati. Para pendidik Kristen diharapkan untuk selalu belajar membangun kharisma dan pola pendidikan dari Sang Guru Agung, Yesus Kristus. Menjadi guru di zaman ini, seperti disampaikan Stephen Covey harus berdiri dengan satu kaki. Guru Kristen, dengan satu kaki harus tetap berdiri pada substansi iman, dan dengan kaki lain harus siap sedia berlari mengejar arus zaman yang terus bergerak maju. Guru Kristen harus setia tetapi juga harus berani bergerak maju. Guru Kristen menjadi orang yang perennial sekaligus progresif. Yesus yang selalu tunduk pada kehendak Allah, tetapi 
selalu hadir dalam cara dan Bahasa dari orang- orang yang dihadapinya. Oleh karena itu berikut ini merupakan saran:

1. Kepada semua orang yang bergerak dalam melaksanakan Pendidikan Agama Kristen kiranya dapat mewarnai pedagogi yang di laksanakan Yesus.

2. Karena begitu hebatnya filsafat Pendidikan Kristen yang di ajarkan Yesus maka hendaknya setiap pengajar menjadikan ajaran Yesus sebagai dasar filsafat pendidikannya.

3. Sekolah dan gereja supaya lebih menggali lagi nilai- nilai pedagogi yang sudah diajarkan Yesus kepada para pengikutnya di dalam Alkitab.

\section{Ucapan Terimakasih}

Peneliti mengucapkan kepada: 1) Pihak yang telah menerbitkan buku- buku sebagai sumber data dalam penelitian ini. 2) Pihak banyak orang yang sudah mendukung secara langsung dan tidak langsung sehingga tulisan ini dapat diselesaikan. 3) Secara khusus kepada pengelola Jurnal Christian Humaniora yang telah berkenan mempublish hasil penelitian ini.

\section{DAFTAR PUSTAKA}

Andrianti, S. (2013) 'Yesus, Taurat Dan Budaya', Jurnal Antusias, 2(3), pp. 112-123.

Bagus, L. (2005) 'Kamus Filsafat, cet ke-4', Jakarta: Gramedia.

Christian Jonch (2007) Yesus Sebagai Guru: Studi Injil Yohanes. doi: https://doi.org/10.36421/veritas.v8i2.190.]

Elena Achkovska Leshkovska and Suzana Miovska Spaseva (2016) 'John Dewey’s

Educational Theory and Educational Implications of Howard Gardner's Multiple Intelligences Theory', 4, pp. 57-66. doi:https://doi.org/10.5937/IJCRSEE1602057A.

Fred, H. (2014) 'John Dewey's Dual Theory of Inquiry and Its Value for the Creation of an Alternative Curriculum', pp. 302-350.

Gartei, R. (2017) 'American progressive education and the schooling of poor children: A brief history of a philosophy in practice', International Journal of Progressive Education, 13(2), pp. 7-17.

Labaree, D. (2005) 'Progressivism, Schools and Schools of Education: An American Romance’, 41(1-2), pp. 275-288. doi: 10.1080/0030923042000335583.

Marlen Tineke Alakaman (2015) 'Yesus sebagai Hamba Kajian Kristologi Dan Relevansinya Pada Pelayan Gereja Di Jemaat GPM Nehemia Sektor Petra', 1.

45 |Pedagogi Yesus Dalam Perspektif Progresifisme Pendidikan ..., Yakobus, Liber, Sampitmo

Jurnal Christian Humanioran | http://e-journal.iakntarutung.ac.id/index.php/humaniora 
Mumuni, T. (2019) 'Critical pedagogy in the eyes of Jesus Christ' s teachings : A historical study', International Journal of Development and Sustainability, 7(1), pp. 340-354.

Nanuru, R. (2015) 'Progresivisme Dalam Pendidikan Di Indonesia', UNIERA, 2 nomor 2, pp. 132-143.

Nanuru, R. F. (2013) 'Progresivisme Pendidikan dan Relevansinya di Indonesia', Jurnal UNIERA, 2, pp. 132-143.

Ndona, Y. (2020) Kebenaran Yang Memerdekakan. Yogyakarta: Gunung Sopai. Olugbenga, F. V. (2015) 'Jesus As A Teacher. Asegun School of Thought.'

Pramudya, W. (2000) 'Doktrin Kerajaan Allah Menurut Walter Rauschenbusch', Veritas: Jurnal Teologi dan Pelayanan, 1(2), pp. 169-179. doi: 10.36421/veritas.v1i2.41.

Purnama, E. (2020) 'Implikasi Kebijaksanaan Yesus bagi Guru Pendidikan Agama Kristen', Pengarah: Jurnal Teologi Kristen, 2(1).

Rebecca Garte (2017) 'American progressive education and the schooling of poor children: A brief history of a philosophy in practice', pp. 7-17. doi: 10.29329/ijpe.

Schönecker, D. and Schmidt, E. E. (2018) 'Kant's ground-thesis. On dignity and value in the ground work', Journal of Value Inquiry, 52(1), pp. 81-95. doi: 10.1007/s10790-017-9603-Z.

Sitorus, H. (2018) 'Refleksi Teologis Kitab Yeremia tentang Pesan Sang Nabi Bagi Orang-orang Buangan', BIA': Jurnal Teologi dan Pendidikan Kristen Kontekstual, 1(2), pp. 267-280. doi: 10.34307/b.v1i2.58.

Tafonao, T. (2020) 'Yesus Sebagai Guru Teladan dalam Masyarkat Berdasarkan Perspektif.

Injil Matius', Khazanah Theologia, 2(1), pp. 52-60. doi: 10.15575/kt.v2i1.8390.

Thompson Mumuni (2018) 'Critical pedagogy in the eyes of Jesus Christ's teachings: A historical study', 7 number 1, pp. 340-354.

Tumbel, D. (2016) 'Kristologi dalam Injil Sinoptik', Kerusso, 1(2). 